\title{
Acoustical Properties of Contemporary Mosques
}

\author{
Case Study of "Bedirye Tiryaki Mencik Mosque”, Manisa
}

\author{
Özgül Yılmaz Karaman', Neslihan Onat Güzel ${ }^{2}$ \\ ${ }^{1}$ Faculty of Architecture, Dokuz Eylul University, Izmir, Turkey \\ ozgul.yilmaz@deu.edu.tr \\ ${ }^{2}$ Faculty of Architecture, Dokuz Eylul University, Izmir, Turkey \\ neslihan.guzel@deu.edu.tr
}

\begin{abstract}
Religious buildings are important for many communities because of their representation of different beliefs. In such structures, the sense of individuality or unity \& togetherness are created according to variable worship activities; these different uses have also different acoustical requirements. In order to create the desired feeling in the space at the required time, rooms should be evaluated in terms of acoustical conditions.

In the study, it is aimed to investigate the objective parameters of sound of the main prayer hall of the Bedirye Tiryaki Mencik Mosque, which was built recently in Manisa (Turkey). It is one of the modern examples of mosque architecture in Turkey. The structure differs from other contemporary examples with the design approach and construction technology. The mosque was built by using prefabrication technology for the entire structure. The acoustical evaluation of this recent example by comparing the recommended values of objective parameters shows that the building has balance between architectural and acoustical design.
\end{abstract}

Keywords: Mosque acoustics; contemporary mosque design

\section{INTRODUCTION}

Religious buildings are important for many communities because of their representation of different beliefs. In addition, on the urban scale, religious structures enrich the cities with their size, decoration, and architectural elements such as domes and minarets. In the religious structures, the sense of individuality or unity \& togetherness are created according to variable worship activities; these different uses have also different acoustical requirements. In order to create the desired feeling in the space at the required time, rooms should be evaluated in terms of acoustical conditions.

In the study, it is aimed to investigate the objective parameters of sound of the main prayer hall of the Bedirye Tiryaki Mencik Mosque, which was built in 2010 in Manisa (Turkey). It is one of the modern examples of mosque architecture in Turkey, built by using prefabrication technology for the entire structure. The acoustical evaluation of this recent example, and a comparison of the results with traditional examples are also objectives of the paper. 


\subsection{Contemporary mosque design}

According to the History of Islam, Muhammed and his followers probably prayed outdoors on their journeys and in tents before the first mosque building was constructed. This was a rectangular building, which was built of mud bricks with a date palm-supported roof, $4 \mathrm{~m}$ high, $26 \mathrm{~m}$ front to back and $30 \mathrm{~m}$ wide. This rectangular form has remained the most popular and traditional of mosque architectural forms [1]. Since those times, many cultures have been built different mosque structures that can differ according to the social, economic, cultural, and ecologic features of the region(s). During its evolution, the functional needs mainly shaped the building, while the symbolic features affected the mosque architecture in the later periods [2].

The need to express physical signs of religion dates back to the insertion of a Catholic church into the Great Mosque of Cordoba in Spain in the fifteenth century, expressing the domination of Christianity in a country which had been ruled peacefully for four centuries by Muslims. Physical forms seem to transmit symbolic messages. The most recognizable of such forms are the minaret and the dome. The Ottoman influence of the tall pencil-thin minaret has been widely adopted because, more than being a pure modern geometric form, the public wants to see them as the indicators of the presence of the society and its values $[3,4]$.

In some studies, the Hagia Sophia is accepted as the model for the mosque architecture of Ottoman History with its dome. "The Hagia Sophia was built to serve as a church in $535 \mathrm{CE}$, but after the Turks took control of Istanbul and converted the church to a mosque, it became a model for other mosques of varying sizes. Instead of rectangles, shapes such as circles, hexagons and octagons became popular because of the strong Turkish influence" [1]. In the era of Architect Mimar Sinan, masterpieces of the mosque architecture were built and they have been affected by many mosque designs up to the present day.
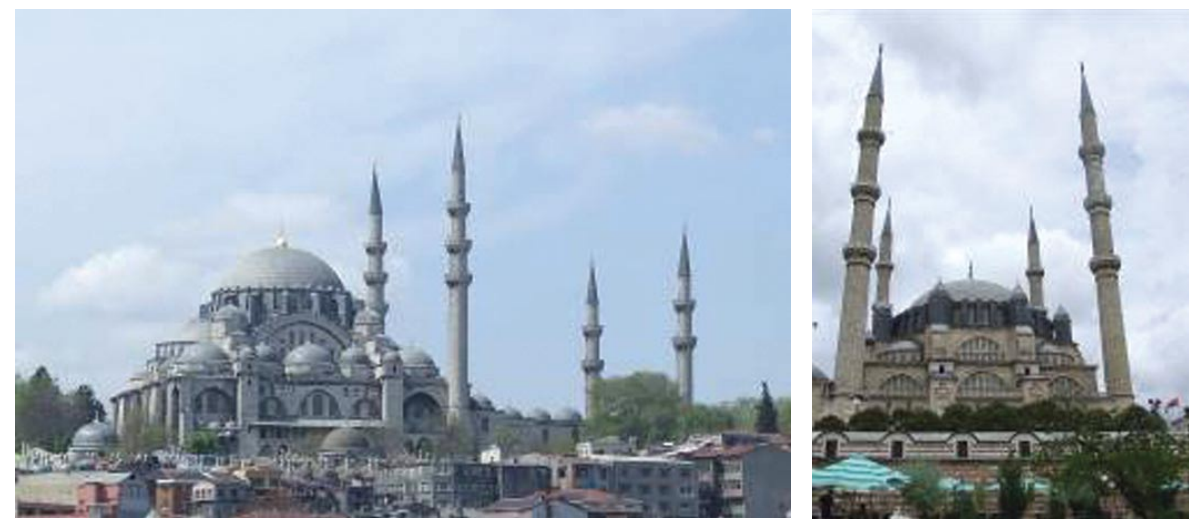

Figure 1. (Left) Süleymaniye Mosque of Architect Sinan (Istanbul/ Turkey) (Right) Selimiye Mosque of Architect Sinan (Edirne/ Turkey) [5].

In mosque designs, where it is very difficult to avoid classical forms, traditional mosque types are repeated rather frequently. Imitating the styles in particular of the 16th century mosques, has been the general approach in mosque designs in Turkey for the last 50 years [ 4 , 6]. This tendency in contemporary mosque design has been also called as historicism, and some examples were also built in non-majority Islamic countries. In Washington D.C. the Islamic center, which was designed by the architect Mario Rossi, is one of the interesting examples in the USA. Rossi, uses the precedent of Mameluke architecture, which he was familiar with, in his design. Another historicist mosque is the Hassan II Mosque of 1993, in Casablanca. It uses the traditional vocabulary of twelfth century Moroccan architecture [3]. 

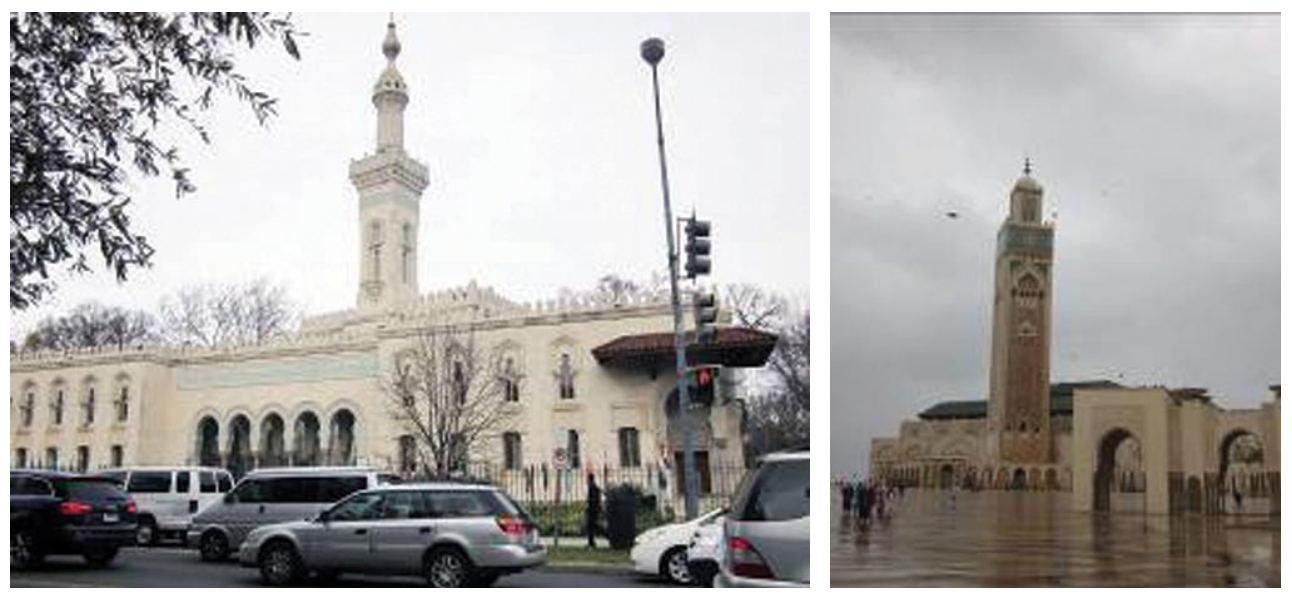

Figure 2. (Left) Islamic center of Washington, general view, façade [7]. (Right) Hassan II Mosque, Casablanca, view to northwest across entrance plaza to minaret [8].

As a general statement, mosque structures can be grouped into two categories; historical and contemporary examples. Contemporary mosque design is quite a complicated issue that architects have to face. It is quite a hard job to create an ideal sacred space without imitating the traditional forms and materials, while society wants to see some symbolic element as mentioned before. For that reason, there are many replicas of the traditional mosques in Turkey; however, some architects strive to find a new design approach that is more compatible with the modern structure/construction techniques or converting and even omitting symbolic elements in order to design a timeless space.

In this context, there are some studies that classify and/or describe the approaches of modern mosque design $[1,9,10]$. According to Uzun (2010), there are two main approaches of today's mosque design; Classic and contemporary. According to the study, "In the classic approach mosques, the architectural forms of "Classic Era Ottoman mosque architecture" are used and repeated, whereas the contemporary approach is seen as a search for different and new forms in mosque architecture. The architectural concerns of new and different forms are more obvious than trying different construction methods and structures, so reinforced concrete is still widely used" [2]. A more detailed classification of contemporary mosque design is also quoted by Dinç Kalaycı \& Şahin Çelik (2014): "Non-monumental stylistic expressions of mosques that appeared after the Second World War to the present time, were listed as the following; (i) vernacular approaches, (ii) revival styles or the replicas, (iii) modern regionalists and (iv)the modern expressions. Of these expressions, the revivalist approaches (the unprincipled ones) were criticized due to their negative contribution to the spiritual and cultural continuity of the religion. Instead, a creative combination of regional and universal characteristics was recommended for contemporary mosque design" [4].

The "Bedirye Tiryaki Mencik" Mosque is considered as an example of "adapted mosques", which were built with the intention to mould traditional and new country elements [1], and were selected for the acoustical evaluation. The mosque has symbolic elements, a dome and a minaret, which were designed with a modern approach and built with contemporary materials. 


\subsection{Definition of the case: Architectural features of Bedirye Tiryaki Mencik mosque}

The Bedirye Tiryaki Mencik mosque is a modern example of mosque architecture located in the Manisa Industrial Park, Turkey. Although it is not a monumental example of mosque architecture, it has a creative combination of regional and universal characteristics, which were recommended for contemporary mosque design. In this context, the Bedirye Tiryaki Mencik Mosque can be evaluated in the group of modern regionalist architectural approach by using a modern construction technology and design approach at the same time.

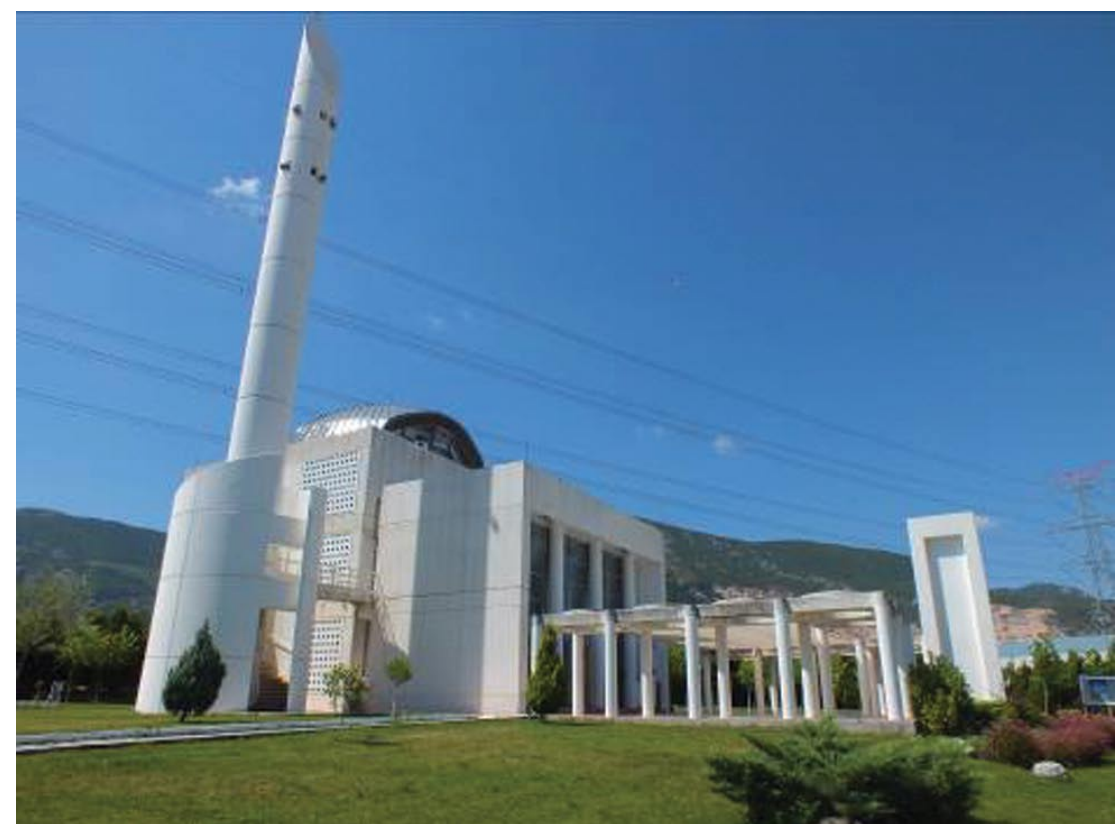

Figure 3. Exterior view of the mosque [11].

In general, the mosque has symbolic elements of the traditional mosques, such as minaret, dome, narthex and courtyard, but the architect introduces his individual design approach to these elements as it is in the whole design of the structure. According to the architect; the Bedirye Mencik Mosque is a result of "a synthesis process" [12].

Prefabrication technology was preferred instead of conventional construction methods of reinforced concrete, which requires high costs for in situ concrete work, mould production and labor, scaffolding for the dome and minaret construction, and for the production of the mosque building. In other words, the limited construction budget has led to the choice of prefabrication technology.

Prefabrication technology whereby all components of a building are prepared in the factory and only installation works are being held on the building site, finds extensive use in the production of building structures such as industrial buildings. The basic principles of the system, which can be called as fully industrialized construction system, are standardization, mechanization, rationalization, and a large number of series production.

Although the mosque was not designed according to the principles of mass production, all the structure was built by precast construction elements. Precast concrete columns, beams, wall panels and the minaret of the mosque were manufactured by the AKAT company. 
The minaret of the mosque was constructed with the company owned moulds, which are used in the production of wind towers. To be able to build the minaret, one unit of the moulds, which are used to produce $70 \mathrm{~m}$ high and gradually tapering towers, had to be temporarily modified. The minaret was completed by superposing the cylindrical units that are produced by the modified mould. The balcony of the minaret (şerefe) is made of steel and hidden in the precast structure.

The main worship area/ prayer hall of the building consists of a grid system with approximately 4,50 $\mathrm{mx} 3,50 \mathrm{mx} 4,50 \mathrm{~m}$ axis length. The narthex was designed as a closed space, directly connected to the cubic main prayer hall, which has three axes in both directions. Prefabricated columns, which have $60 \times 60 \mathrm{~cm}$ and $70 \times 70 \mathrm{~cm}$ cross-sections, were produced to a height of 3 stories. Prefabricated beam elements were placed on the hidden ledges of these columns.

The dome structure was constructed with a steel frame, which was prefabricated completely and placed on the main prayer hall with the help of a crane. The elliptical dome was designed with a cropped edge on the entrance façade to obtain natural light inside from the north. The truncated elliptical dome sits on an octagonal space that is framed with beams of different lengths.

Some of the non-bearing walls were made of large concrete panels. Prefabricated wall panels were covered with thermal insulation material and white cement mosaic plaster. Thus, it would not be necessary to have an additional plaster layer inside and outside of the building.

The mihrab is designed as a triangular shaped niche two stories high, and highlighted on the facade of the building structure. Interior surfaces of the mihrab are covered with ceramic tiles.

All the facades of the mosque have large window openings. These openings are covered with the grid-shaped cages that providing filtered light into the main worship space, outside. There are also circular shaped plasterboard panels placed in front of the windows interior space.

Apart from a small part of the entrance part, which is covered with ceramic tiles, the floor of the mosque is covered by carpet. The minber is also designed as a modern approach and made of steel and glass.
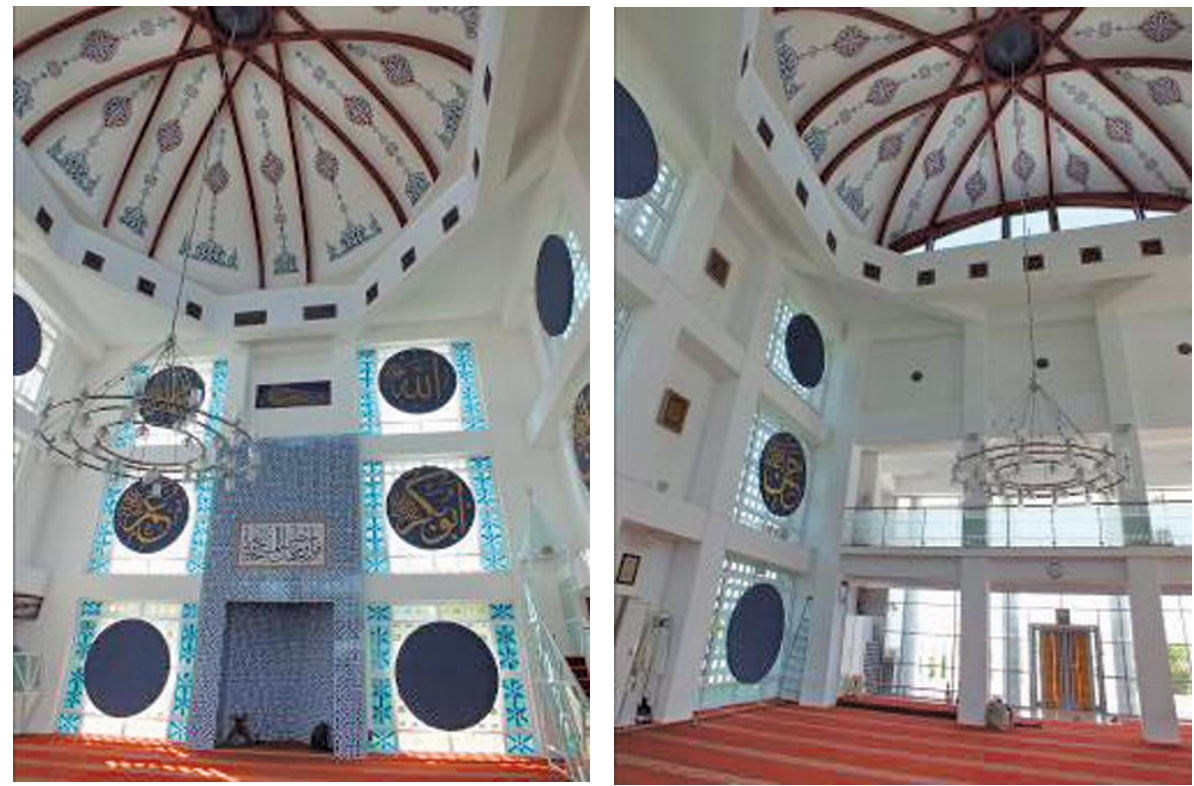

Figure 4. Interior view of the mosque [5]. 
It can be seen that the last prayer section, usually the semi open entrance area just before the main hall, of traditional mosques are closed in a variety of ways depending on the needs of today. For that reason, instead of omitting the last prayer section, Şükrü Kocagöz, who is the architect of the mosque, preferred designing a closed entrance space, as a continuation of the main worship section. The solution of the designer is two stories high curtain wall with a transparent facade of the entrance hall to create also the continuity of relationship with the exterior visually. The height of this part is lower than the main hall, and it is covered by three small truncated elliptical domes, which were produced in a similar way to the main dome. In this part, there is a place for women located on a mezzanine floor, accessed by the outside of the building. The stairs that surround the minaret on the ground floor level, also provide access to the women's prayer area located on the first floor. The courtyard of the mosque is enclosed by porticos made of prefabricated elements.

\section{ACOUSTICAL REQUIREMENTS IN MOSQUES}

Acoustic perception in some special spaces such as religious buildings is considered as important as the visual perception [13]. In worship spaces, the human perception is affected in terms of visual and acoustic elements. The purpose of these places is to make prayers feel close to God and to create spaces where the acoustical perception is important and thoughts and emotions can be expressed by worship. The choice of acoustical parameters, which should be used for the evaluation the existing buildings, is an important issue.

Activities that are mainly carried out in a mosque are listed as; prayer (either individually or in a group led by a leader; the Imam), public speaking, preaching (attendance at a sermon being delivered on its own or within the Friday noon prayers), lecturing, and Quran recitations (listening to or reciting some verses from the Holy Quran) [14, 15, 16]. All these activities require a high level of speech audibility and intelligibility. To ensure good listening conditions, acoustical needs must be considered in the design phase [15]. The main prayer hall consists of different building elements to maintain the activities that are listed above; such as the "mihrab", "minbar", and "müezzin gallery". Khutba is read on the minbar located on the right side of the mihrab. The minbar provides the visual connection between listener and speaker because it includes steps. Besides this, the speaker on the steps in the minbar during the Khutba and sermon speaking provides a positive impact in acoustic conditions. The muezzin gallery is made for the muezzins to sit on the high platform, give the "tesbihat" sounds, and repeat what the imam is saying. This situation helps to keep the sound source over the audiences, and to stabilize the sound energy in the volume [17]. In the mosques, the feeling of individuality is desired in praying, and the feeling of unity is desired in the reading of the Holy Quran, and hymns, etc. Therefore, mosques are places which include both speech and music. However, the instrumental music does not take place in the mosques because it is not mentioned in the Holy Quran. In practical terms, speech and its intelligibility are the major acoustical considerations in the acoustical design of a mosque.

In the study, the methods and parameters, which have been used in recent studies, are investigated, as are the similar methods and parameters for assessment and evaluation of mosque structures. Most of the time, existing recommendations, which are developed for the speech auditoriums or dramatic theatres, have to be used to evaluate the acoustic quality of the mosques. In other words, unlike auditoriums, there are no defined recommendations or rules for the acoustical parameters inside mosques. However, regarding mosques, the elaboration of general sound parameters requires a specific understanding of the acoustical and spiritual environment expected in such structures. 
In some studies, there have been some recommendations developed for the acoustical parameters by considering the activities in mosques $[15,18]$. To show the sacredness of religion, historical mosques were often built in large volumes by using high and wide dome structures. Acoustical problems due to the large volumes are expected in these mosques like large cathedrals [1]. However, some prevention of this problem was considered. For example, the floors of mosques are covered by carpets, which are made of an absorptive material, provide acoustic comfort. By using sound absorbent surfaces, most of the sound energy cannot be reflected back, and it prevents long reverberation times. In Sinan mosques, the minbar and muezzin gallery are made by using perforated panels, which reduce the sound energy level and provide acoustic comfort [19].

The acoustical quality of the mosques has been discussed in the literature, and studies have mostly focused on the analysis of the ancient and/or contemporary examples of the mosque architecture. Such studies may include single mosque cases [17, 20, 21, 22] or some of them include comparisons of mosques to other mosques [14, 16, 19, 23, 24, 25, 26] or comparisons of mosques to other worship spaces (churches and/or synagogues) [27].

Although acoustics is an important parameter of mosque design, most of the time it is not considered at the beginning of architectural design in contemporary examples. Achieving the required level of listening conditions is highly dependent on how mosques interiors are designed. Maintaining a closer distance between worshipper and sound source will improve the intelligibility figures and makes them less dependent on the mosque's volume. In most of the contemporary examples, acoustical performance has been found to be poor because of the high reverberation time and background noise [6, 28].

The intensive use of hard and reflective surfaces such as, marble, tiles, and glass are quite common because of their aesthetic value and ease of maintenance, and the increase of the reverberation time. Also, as the mosque volume increases, the reverberation time increases accordingly. The increase of reverberation time produces a decrement of intelligibility and clarity of sound. These dependent relationships have to be considered by the designers of mosques and necessary treatment(s) should be implemented to room surfaces at the beginning phase of the design $[15,26]$.

In this context, recent studies show that if acoustical design is evaluated as an integrated part of the architectural design, results can be satisfactory. Moreover, cooperation in the early stages will save considerable costs, which might be spent to relocate some of the building elements or to change their materials [29]. Several acoustical parameters are utilized for the evaluation of the speech audibility and intelligibility. Commonly assessed parameters in the acoustical analysis of mosques are similar to the ones used in the speech auditoriums and can be listed as reverberation time (T60, T30), early decay time (EDT), clarity (C80), sound pressure levels (SPL-A), speech transmission index (STI) or articulation index (AI) $[16,29]$. Computer simulation techniques and/or site measurements are commonly used in the research.

In the recent study by Elkhateeb, et.al (2015), the three reasons that differentiate mosques from the classical speech rooms are discussed. According to the research, the recommended shape of mosques, the nature of the sound source that is used in mosques (its position and orientation), and the effect and behavior of the worshippers inside the mosque effect the acoustical design of the prayer room. "For the first, it is preferable for Masjids to have a right prismatic form with a rectangular base, and its long side facing the Holy Ka'aba in Makkah. Regarding the second, the only allowed sound source inside a Masjid is a human male voice, who recites verses from the Holy Qur'an, or delivers a speech in a formal Arabic language. The recitation must be performed in a slow rhythmic tone, and the speech must be delivered in a medium to slow speech rate. The sound source is oriented opposite to the worshippers during the prayer, but elevated and facing during the speech. For the last reason, the absorption characteristics of worshippers completely depend on their body postures according to the 
method of prayer in Islam. In addition, those worshippers are not allowed to speak during the actual performance inside the Masjid; it is obligatory to keep silent, which means a very low background noise" [18].

In Table 1, short definitions and the required ranges of parameters, which are used in the acoustic evaluation, are summarized.

\begin{tabular}{ll}
\hline Parameter & Definition \\
\hline $\begin{array}{l}\text { Reverberation Time } \\
\text { (T, T30) (s) }\end{array}$ & $\begin{array}{l}\text { T is defined as the time it takes for the sound level in } \\
\text { the room to decrease by } 60 \mathrm{~dB} \text { after a continuous sound } \\
\text { source has been shut off. In practice, the evaluation is } \\
\text { limited to a smaller interval of the decay curve, from } \\
-5 \mathrm{~dB} \text { to }-35 \mathrm{~dB}(\mathrm{~T} 30) \text { below the start value; but still } \\
\text { relating to a } 60 \mathrm{~dB} \text { decay [30]. }\end{array}$ \\
\hline $\begin{array}{l}\text { Early Decay Time } \\
\text { (EDT) (s) }\end{array}$ & $\begin{array}{l}\text { an alternative measure, EDT has turned out to be better } \\
\text { correlated with the reverberance perceived during } \\
\text { running speech and music. This parameter, like T, also } \\
\text { measures the rate of the decay; but now evaluated from } \\
\text { the initial part, the interval between } 0 \text { and }-10 \mathrm{~dB} \text {, only } \\
\text { and multiplying it by } 6 \text { for corresponding with RT values } \\
{[30] .}\end{array}$ \\
\hline
\end{tabular}

\begin{tabular}{ll}
\hline Distinctness & D50 is mostly regarded as a parameter related with \\
(D50) (\%) & speech, and higher values are expected for better \\
& intelligibility. \\
& The relationship between D and the syllable intelligibility \\
& is shown in the figure on the right. Obviously, it is a \\
& useful descriptor for speech intelligibility [33].
\end{tabular}

Speech Transmission
Index (STI)

Speech Transmission Index, STI has also been investigated since it is one of the most popular parameters to evaluate the intelligibility.

An equation that takes into consideration the contribution of the direct sound and interfering noise in the calculated STI was provided by Houtgast and Steeneken in 1980. It represents the squared impulse response as a component of the direct sound and reverberant field [15].

Optimum values

1,2 s.- 1,4 s. for volume of $2750 \mathrm{~m}^{3}$ [15].

$\mathrm{T}_{\mathrm{OM}}=\mathbf{0 , 8 2 2} \mathrm{V}^{0,1080}(\mathbf{s})[31]$.

$\mathrm{T}_{\mathrm{OM}}=1,93 \mathrm{~s}$.
$\mathrm{RT}-(\% 10 \mathrm{x}$ RT $) \leq \mathrm{EDT}$

$\leq \mathrm{RT}+(\% 10 \mathrm{x} \mathrm{RT})[32]$.

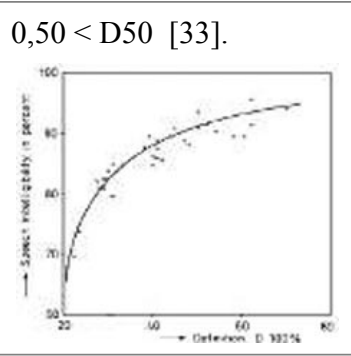

$0,00-0,30(\mathrm{Bad})$

$0,30-0,45$ (Poor)

$0,45-0,60$ (Fair)

$0,60-0,75$ (Good)

$0,75-1,00$ (Perfectl) [34]

$>0.5$
Clarity of Speech

(C50) (dB)
Another measuring tool of intelligibility is C50. Here the ratio of energy before and after 50 milliseconds in decibels is measured..

The integration of sound arrivals within $50 \mathrm{msec}$ with direct sound is due to the human nature of our ears [15].
Values above the zero line depict more energy arrivals before the $50 \mathrm{msec}$ than after it what enhances the direct sound and increases clarity [15].

The noise level, that is the sound pressure level of the noise, in rooms should be low enough so that it will not interfere with the hearing and with the production of speech. Background noise can be due to the environmental noise or can already exist within the prayer zone due to $\leq 30[27]$ 25-30 dBA [1]

\section{Background Noise Level (dBA)} the HVAC or other mechanical equipment.

Table 1. Investigated acoustical parameters and optimum values for mosques/ speech rooms 


\section{ACOUSTIC MEASUREMENTS IN THE 'BEDIRYE TIRYAKI MENCIK' MOSQUE}

Acoustical field measurements are held in accordance with ISO 3382-2:2008 [35]. The B\&K (Type 4292-L) standard dodecahedron omni-power sound source is used in acoustical signal generation with the B\&K (Type 2734-A) power amplifier. The impulse response at various measurement points is captured by a B\&K (Type 4189ZC-0032) microphone incorporated into the hand-held analyzer (B\&K-Type 2250-B). DIRAC Room Acoustics Software Type 7841 v.5.5 is used for both generating the MLS signal and evaluating the measured impulse response data for eight receiver positions.

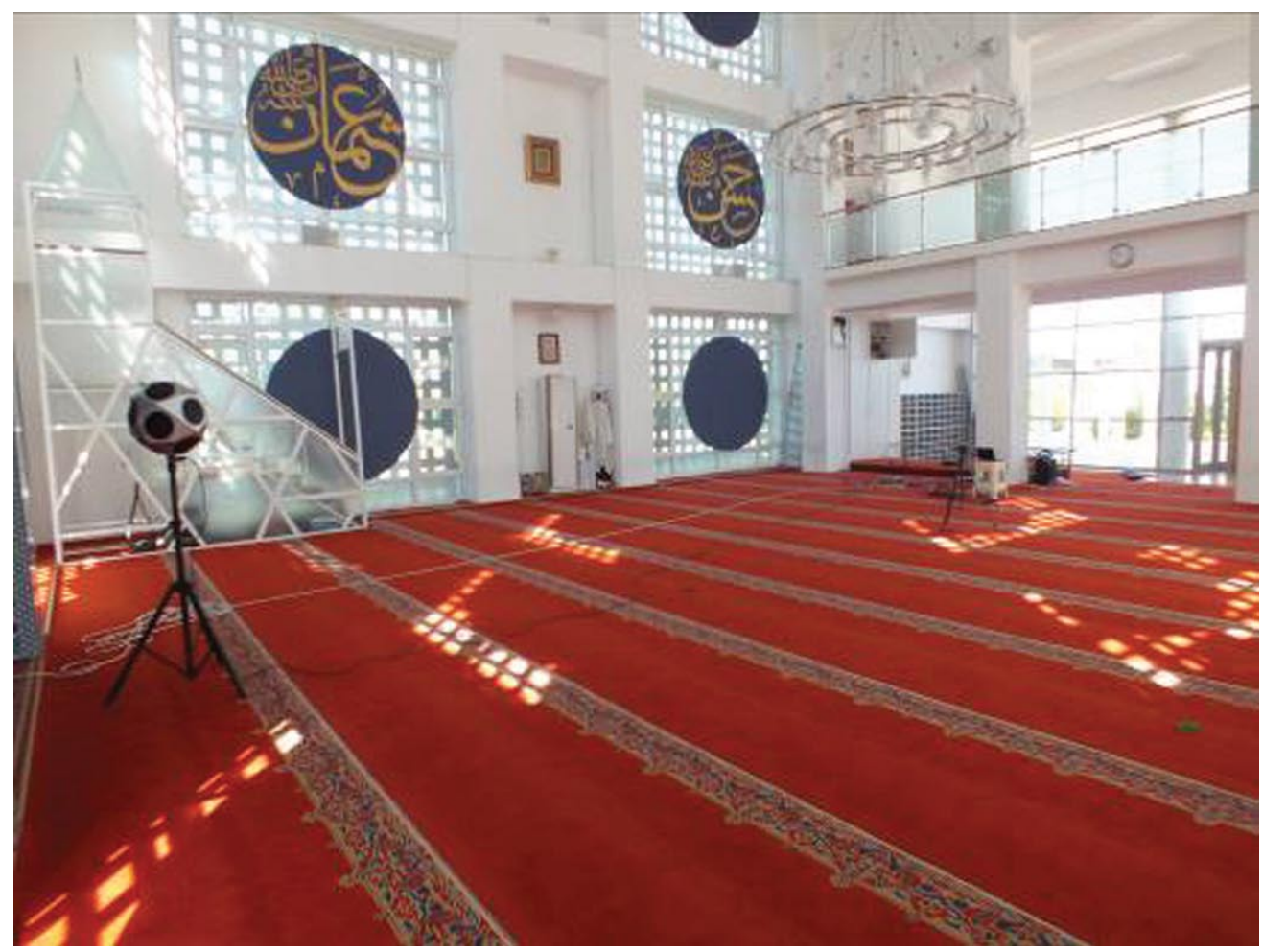

Figure 5. Measurement equipment [5].

Field tests are held in the main prayer hall on the ground floor in the empty/unoccupied area of the mosque. The omni power sound source is located at the front of the mihrab at $1.50 \mathrm{~m}$ height considering the position of the standing Imam (Figure $5 \& 6$ ). Eight receiver points are defined (Figure $5 \& 6$ ), and for each receiver location a microphone is placed roughly at the height of the head of a seated person on the floor, $0.85 \mathrm{~m}$, and adjusted by a holder tripod.

The B\&K Hand-held analyzer (model $2250 \mathrm{~B}$ ) was also utilized to measure Leq. The measurements have been considered in the case of HVAC "off", and $33.4 \mathrm{~dB}$ LAeq was measured. That is an acceptable value when comparing the expected levels of background noise (table 1).

The measured values of the T30, EDT, C50, D50, and STI parameters of the Bedirye Tiryaki Mencik Mosque are shown in the graphs below. 

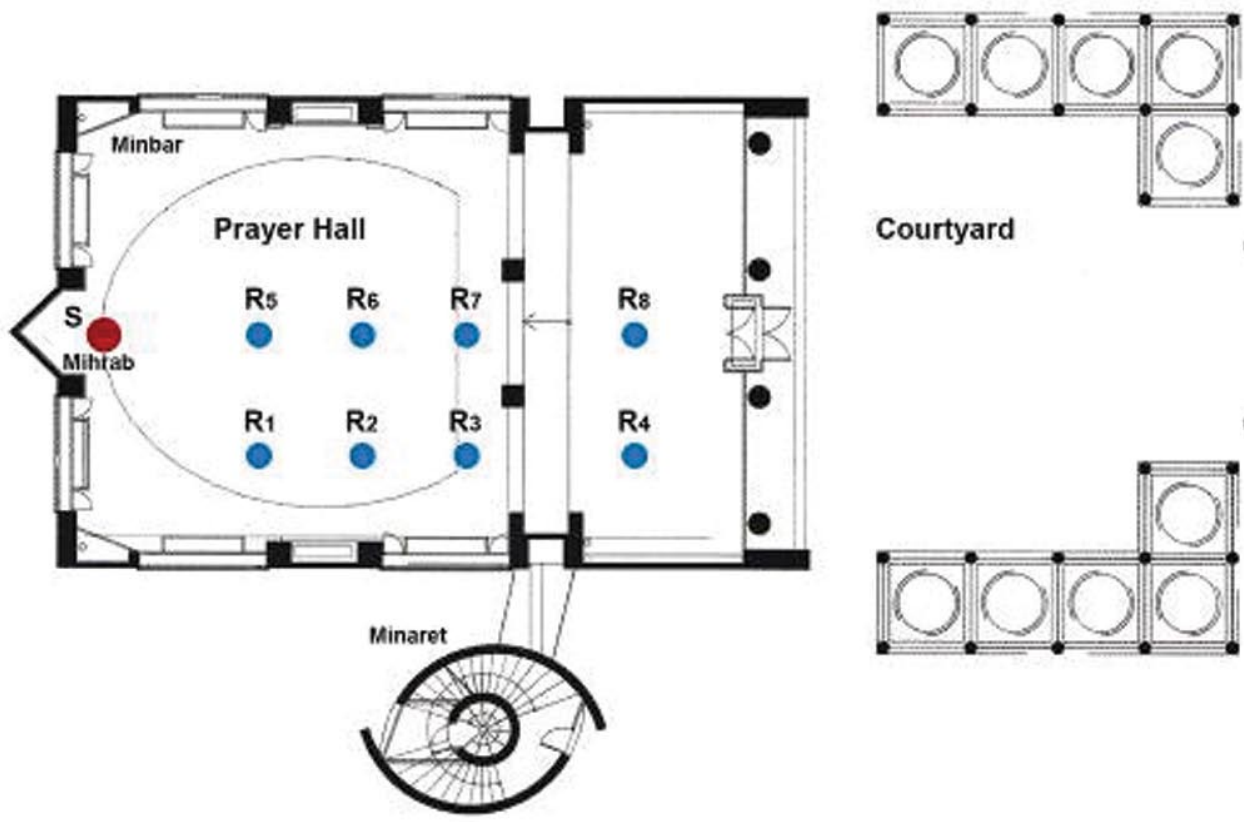

Courtyard
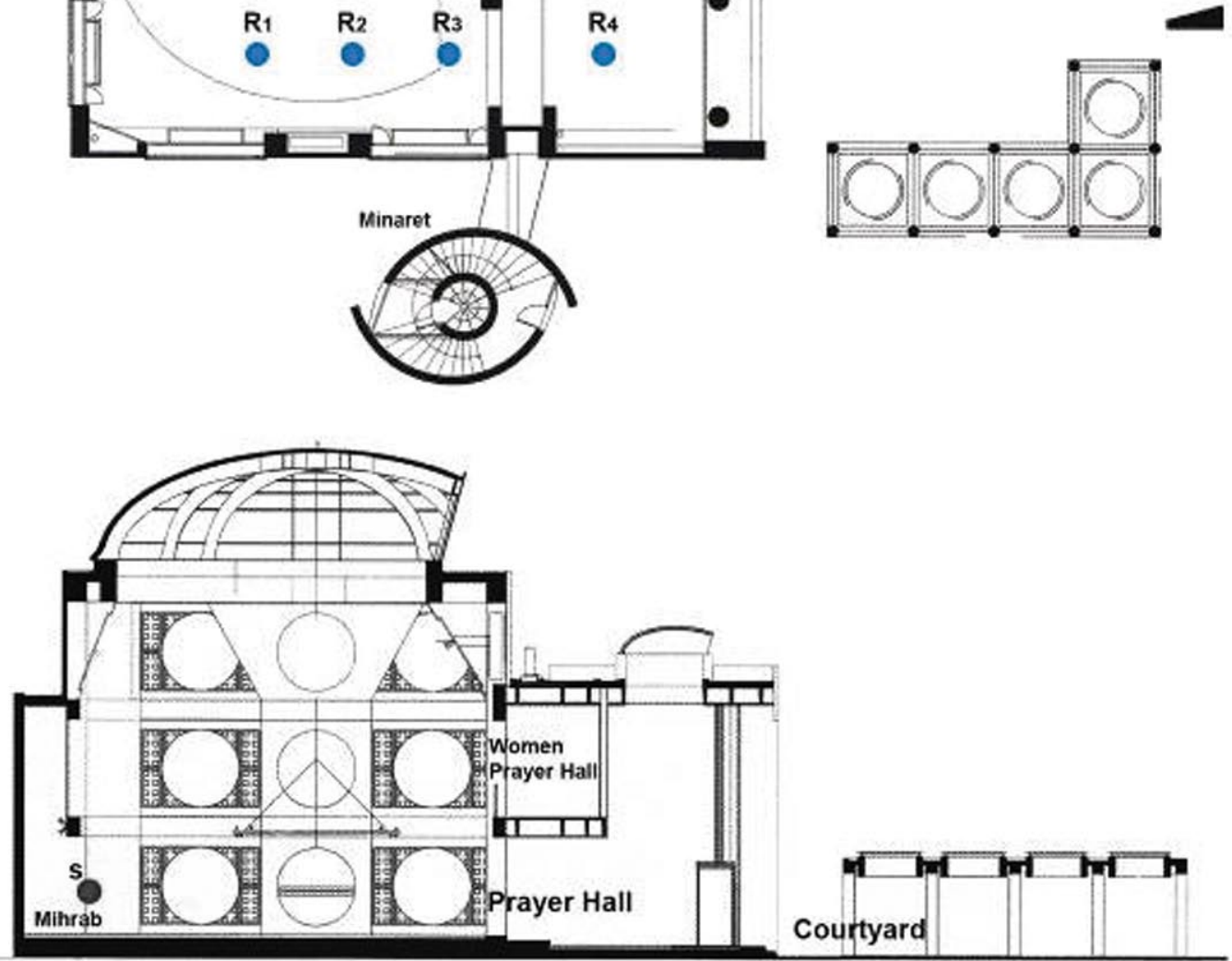

Figure 6. Plan (top) and section (bottom) of the building with source and receiver points (Modified from Şükrü Kocagöz) [12].

\subsection{Reverberation time (T30)}

The chart in Figure 7 shows average T30 values of the mosque for eight receiver points. The values are quite similar for each receiver point and decrease in high frequency range. The low values at high frequency are mostly caused by used sound absorbing materials in the mosque such as carpets, covered fabric mats, and rugs.

\subsection{Early decay time (EDT)}




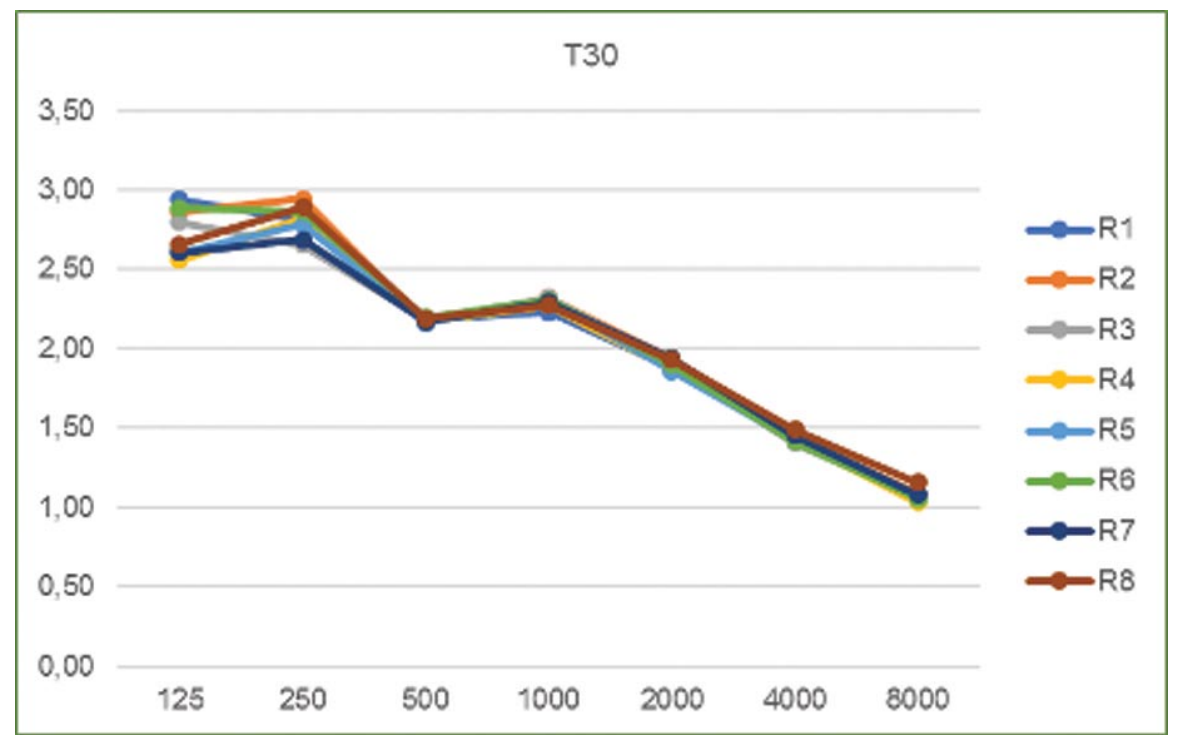

Figure 7. Measured T30 values of the receiver points

The EDT values of the receiver points are also quite similar; especially for the midfrequencies that important for the speech. Furthermore, the similar inclination of the T30 and EDT graphs shows the uniform distribution of the sound within the room.

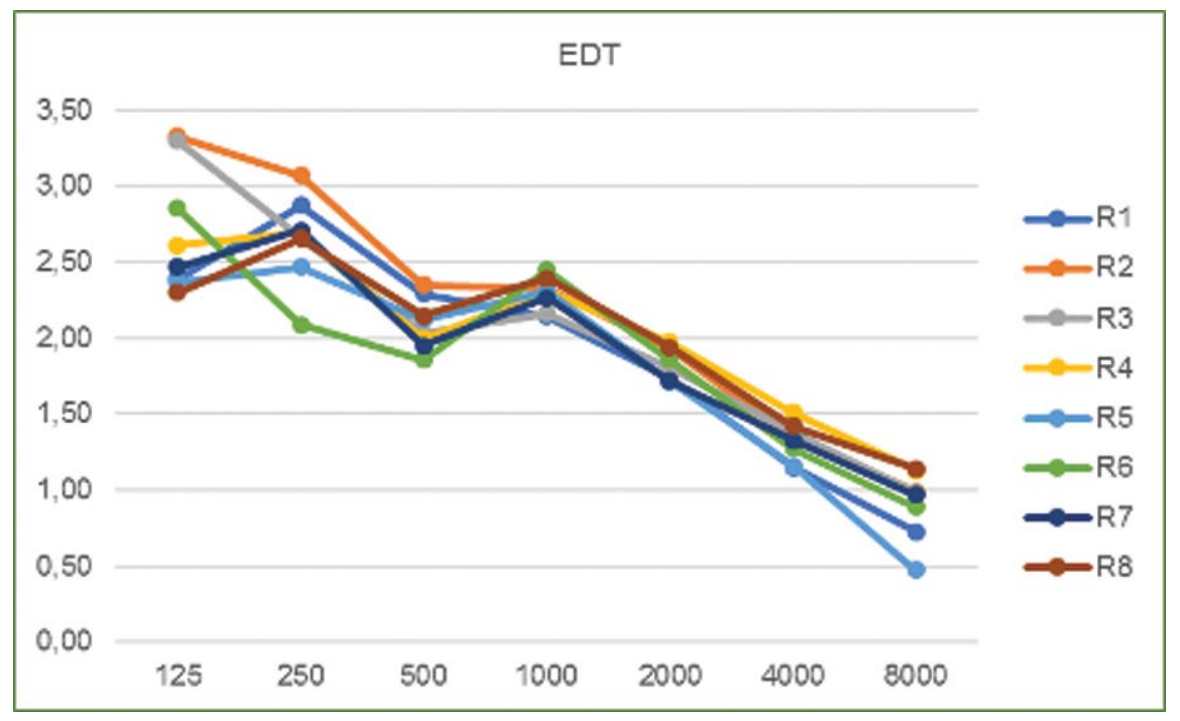

Figure 8. Measured EDT values of the receiver points

\subsection{Distinctness (D50)}

The D50 values are given in Figure 9. Generally, the values above 50\% are considered as sufficient for the distinctness of the speech; however, in the graph, some of the receiver points have lower values of D50. 


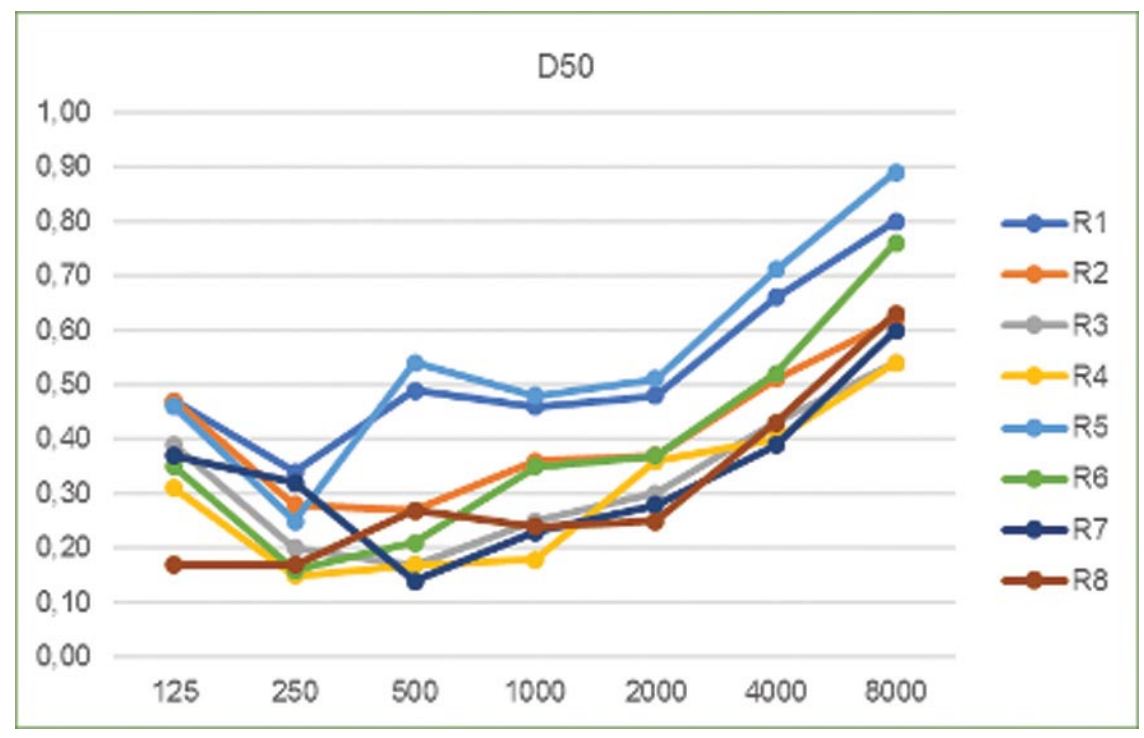

Figure 9. Measured D50 values of the receiver points

\subsection{Clarity of speech (C50)}

According to the graph in Figure 10, the C50 values of the mosque are better in the first row, similar with the D50 values.

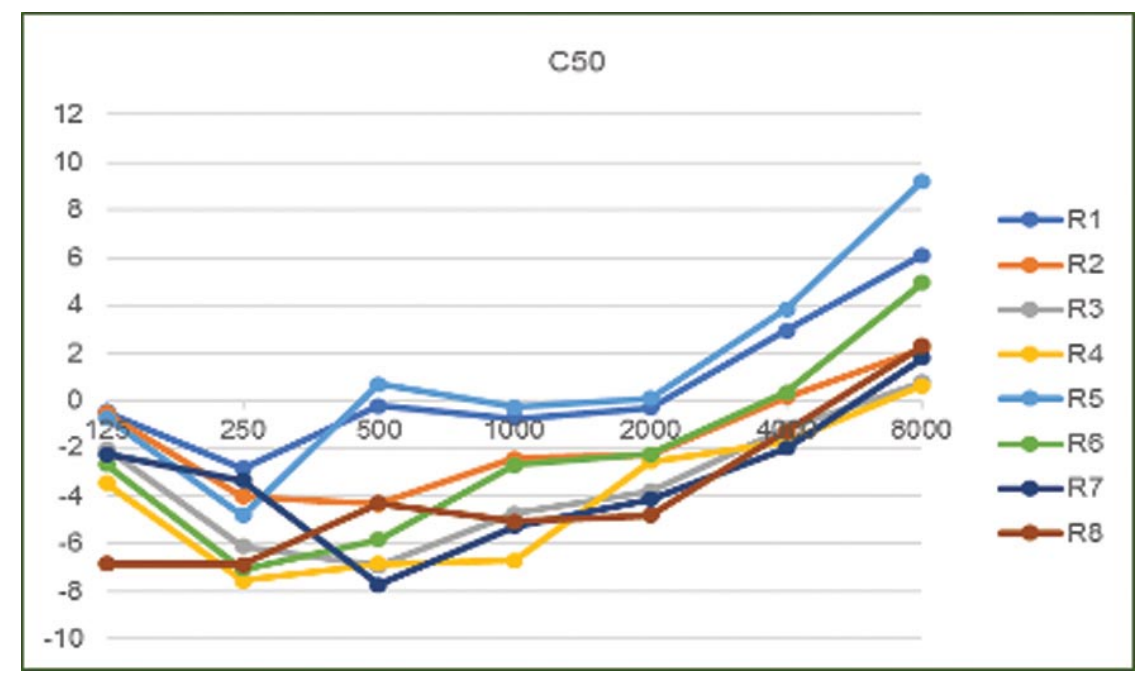

Figure 10. Measured C50 values of the receiver points

\subsection{Speech transmission index (STI)}

According to the graph in Figure 11, the STI values of receiver points are obtained in the same value range close to each other. The values of the mosque are between 0.45 and 0.6 , which can be evaluated as "fair". 


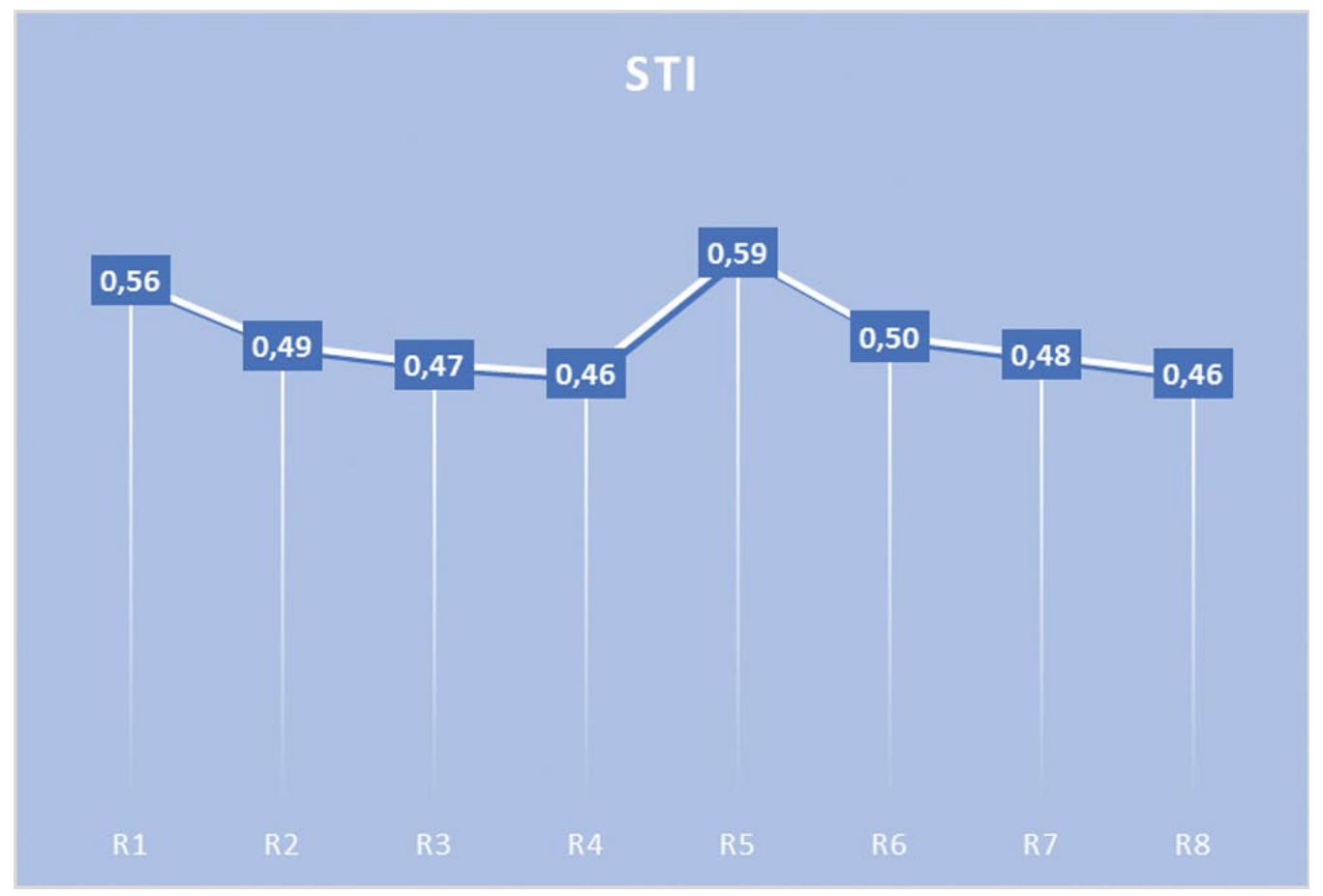

Figure 11. Measured C50 values of the receiver points

\section{CONCLUSION/ EVALUATION OF RESULTS}

As mentioned while defining the acoustic requirements for mosques, there are some criteria, in other words, optimum values for comparison with the obtained values in order to evaluate the acoustic quality of the main prayer hall of the Bedirye Tiryaki Mencik Mosque. The summary of the measured values of the mosque are listed in Table 2. Although there is lack of certain acoustic data, which is specifically oriented to mosques (masjids) [31], the acoustic requirements for achieving the desired conditions in the prayer hall of the mosques are summarized as follows [36];

- lower but controlled RTs for mid and high frequencies in comparison to low frequencies for intelligibility of sermons

- higher but controlled RTs for low frequencies in comparison with mid and high frequencies for enhancing the spiritual aspects of musical rites balanced sound absorption of interior surface materials over frequency range

- $\quad$ sufficient sound strength/level or loudness in prayer positions

- $\quad$ even sound distribution among prayer positions

- minimal acoustical defects such as sound glare, echoes, and dead spots

- low background noise that does not mask speech intelligibility

The most effective parameter which should be considered is the reverberation time (T30) to evaluate the acoustical quality of the prayer hall. Most studies conclude that la ong reverberation time inside mosques is expected by being compared to the classical speech rooms. 


\begin{tabular}{|c|c|c|c|c|c|}
\hline \multirow[t]{2}{*}{ Parameter } & \multirow[t]{2}{*}{ Limits } & \multicolumn{3}{|c|}{ Frequency $(\mathrm{Hz})$} & \multirow{2}{*}{$\begin{array}{l}\text { Optimum } \\
\text { values } \\
\text { (table 1) }\end{array}$} \\
\hline & & 500 & 1000 & 2000 & \\
\hline \multirow[t]{3}{*}{ T30 (s) } & Minimum & $2,16(\mathrm{R} 2)$ & $2,23(\mathrm{R} 1)$ & 1,86 (R5) & \\
\hline & Average & 2,18 & 2,29 & 1,90 & 1,93 \\
\hline & Maximum & 2,20 (R6) & $2,32(\mathrm{R} 2)$ & $1,94(\mathrm{R} 2)$ & \\
\hline \multirow[t]{3}{*}{ EDT (s) } & Minimum & 1,86 (R6) & 2,14 (R1) & $1,71(\mathrm{R} 5)$ & \\
\hline & Average & 2,10 & 2,30 & 1,83 & 1,74 - 2,12 \\
\hline & Maximum & 2,29 (R1) & 2,45 (R6) & $1,98(\mathrm{R} 4)$ & \\
\hline \multirow[t]{3}{*}{ D50 (\%) } & Minimum & 0,14 (R7) & 0,18 (R4) & 0,25 (R8) & \\
\hline & Average & 0,28 & 0,32 & 0,37 & $\mathbf{0 , 5 0}$ \\
\hline & Maximum & 0,54 (R5) & 0,48 (R5) & $0,51(\mathrm{R} 5)$ & \\
\hline \multirow[t]{3}{*}{ C50 (dB) } & Minimum & $-7,72(\mathrm{R} 7)$ & $-6,71(\mathrm{R} 4)$ & $-4,82(\mathrm{R} 8)$ & \\
\hline & Average & $-4,43$ & $-3,48$ & $-2,50$ & $\begin{array}{l}\text { Positive } \\
\text { values are } \\
\text { recommended }\end{array}$ \\
\hline & Maximum & 0,69(R5) & $-0,27(\mathrm{R} 5)$ & $0,10(\mathrm{R} 5)$ & \\
\hline
\end{tabular}

Table 2. Measured values of mosque

"High Reverberation Time will lead to unacceptable intelligibility levels, while low reverberation time will result in so called "Dead" spaces where spiritual ceremonies lose the attention of the worshippers." [15]. "Although the speech intelligibility is the upmost priority, a mosque is not a classical speech room as a conference hall or auditorium. The acoustical environment of a mosque should satisfy the spiritual aspects of worship, while enabling the most proper environment for the perception of the imam and muezzin conveys. The functional space of a mosque should not be acoustically dull, as well as not excessively reverberant" [37].

"There is much evidence to prove that long reverberation inside masjids is recommended because it enhances its spiritual role, whereas a short reverberation is neither functional nor reasonable. It appears that the optimal reverberation curve Tom suggested by Kayll, is the most appropriate. values on this curve compromise the wishes of Imams and the requirements of the worshippers" [31].

Based on the curve introduced by Kay1l, Elkhateeb et.al. suggest a formula from which the values of TOM (optimum T for Masjids) can be calculated dependent on the volume of the prayer hall (Table 1). According to the authors, a masjid should maintain a reverberation that is almost double the reverberation in a speech room of the same volume. "Accordingly, $\mathrm{V}_{\mathrm{p}}$ (volume for per person) for masjids should be at least double the recommended $V_{p}$ for speech rooms, (i.e., 6-10 m3/person in masjids). This conclusion is in good agreement with the $\mathrm{V}_{\mathrm{p}}$ of some historical Ottoman masjids. 
As the reverberation time increases, it is expected that the optimal boundaries of the two indicators - definition measure C50 and center time TS - will also change. For masjids, the optimal Ts may be near that of the music to enhance the spatial impression of the room, which is essential in such spaces" [31].

Within this context, measured values in the mosque are summarized and compared with the optimum values in table 2 . In the table, also maximum and minimum values of measured parameters are shown depending on the receiver points.

In the Bedirye Tiryaki Mencik Mosque, T30 is measured 2,12 s (average of 500-1000-2000 $\mathrm{Hz}$ ), and it seems longer than Orfali's limit, which is 1,2-1,4 s. (Table 1), for mosques with this volume. In the same study, he founds that this limit can be extended to $+0,4$ s., because of the spiritual atmosphere of the prayer hall [15].

However, $2.12 \mathrm{~s}$ is still longer than 1,8 s. and slightly longer than 1,93 s., which is calculated by using the formula suggested by Elkhateeb et.al. There may be some intelligibility problems, especially in the last prayer section of the mosque. On the other hand, $\mathrm{Vp}$ is found about 10 $\mathrm{m}^{3} /$ person in the Bedirye Tiryaki Mosque, and it is exactly the same value that is recommended for the mosques by the study of Elkhateeb, et.al (2016) [31].

EDT values are also found very close to T30 values; this can be concluded as uniform distribution of sound field in the Bedirye Tiryaki Mencik Mosque. In general, the optimum values of the EDT are given as $\pm 10 \%$ of the RT (table 1 ).

When the values of D50 and C50 parameters are evaluated, the results are not very satisfying; especially for the listeners at the last prayer section. D50 values are expected to be at least 0.20 and higher values to achieve $50 \%$ of the speech intelligibility value [33], and in some rare points values are under 0,20 . However, average value of 0,32 seems quite acceptable with this long reverberation time. Similarly, C50 values are below zero line, especially at the back part of the hall because of the longer source-listener distance.

Overall, the STI rating is also found "fair", which is between 0,45-0,60 in line with the D50. To improve speech intelligibility, the reverberant sound can be reduced relative to the useful direct sound and also using sound absorptive materials in especially in the last prayer section of the mosque.

The central dome, which dominates the entire structure, placed over the cubical body is described as the most distinctive feature of XVI century Ottoman Architecture. In addition to this great dome, 3 smaller domes on the last prayer section of the prayer hall are thought to reflect the common taste of architecture of the Architect Sinan [24].

Cenabi Ahmet Pasa Mosque (1565-1566), located in Ankara, is an example of XVI century with quite a similar capacity and volume of the Bedirye Tiryaki Mencik Mosque. The architect of the Cenabi Ahmet Pasa Mosque is unknown; however, some architectural historians have seen the skill of Architect Sinan in the method of design and structure, and attributed the building to him. The mosque has a square plan with $13.9 \times 13.9 \mathrm{~m}$ dimensions and a central dome with $14.40 \mathrm{~m}$ diameter. It has approximately $2900 \mathrm{~m}^{3}$ volume with capacity of 250 people. It means there is $11,6 \mathrm{~m}^{3}$ volume per person, and an average reverberation time for the mid-frequencies of the prayer hall was measured about 3,6 s. [24]. And this value of T30 is much longer than Bedirye Tiryaki Mencik Mosque.

Although the Bedirye Tiryaki Mencik Mosque is a modern example of mosque architecture with modest dimensions/ capacity when compared to the classical Ottoman Mosques, it is a result of a synthesis process of this domed mosque typology of XVI century Ottoman Architecture with its elliptical dome on the cubical body and three smaller domes with similar geometry to the last prayer section. 
Domed mosque typology can cause sound focusing and an uneven sound distribution within the space, but in the Bedirye Tiryaki Mencik Mosque dome does not cause such problems because the center of the dome is not at the receiver/listener's ear height.

The parallel reflective walls can also be an important factor for strong late sound reflections; especially the big glass surface of the entrance facade of the mosque. Circular shaped plasterboard panels placed in front of the windows on the side walls and beam and column surfaces can be evaluated as useful irregularities/ ornaments, and they can be of use on the glass surface of the last prayer section.

Another important parameter that affects speech intelligibility together with RT is the background noise level, and it is measured slightly higher than recommended values, although the mosque is in a distant part of industrial park. In the future, this issue should not be ignored; especially when some mechanical equipment is installed for air conditioning.

By considering all the results, the acoustic quality of the prayer hall can be evaluated as quite satisfactory; especially when considering the recent arguments on the reverberation time, even though all the reflective surfaces, such as large window openings and the entrance façade, which is made of glass, and the domed mosque typology. In short, the most common challenge of the mosque design, optimizing reverberance versus intelligibility also emerges in the Bedirye Tiryaki Mencik Mosque, but it seems to achieve the balance between architectural and acoustical design.

\section{REFERENCES}

[1] KLEINER, M., KLEPPER, D., \& TORRES, R., Worship Space Acoustics. J. Ross Publishing Inc., 2010.

[2] UZUN, Ç., The Examination of Today's Mosque Architecture in the Context of Form, Function and Technology. Izmir: Dokuz Eylul University - The Graduate School of Natural and Applied Sciences, (2010).

[3] KHAN, H.-U., Contemporary Mosque Architecture. ISIM Review, 21, (Spring 2008), 52-53. Retrieved from https:// openaccess.leidenuniv.nl/bitstream/handle/1887/13326/review_21.pdf?sequence=1

[4] DINÇ KALAYCI, P., \& ŞAHIN ÇELIK, E., Public's Judgment on Contemporary Mosque Design Approaches. Gazi University Journal of Science, 27(4), (2014), 1185-1194.

[5] Photographs by ÖZGÜL YILMAZ KARAMAN, (2010, 2016)

[6] KARABIBER, Z., Acoustical problems in mosques: A case study on the three mosques in Istanbul. The Journal of the Acoustical Society of America, 105(2), (1999), 1044.

[7] SMITH, S. C., General view, facade, Islamic Center of Washington. Aga Khan Documentation Center at MIT. 2014, Retrieved September 2016, from http://archnet.org/sites/358/media_contents/95255

[8] GEWERTZ, A., View to northwest across entrance plaza to minaret. Hassan II Mosque, Casablanca, Morocco. 2011, Retrieved September 2016, from http://archnet.org/sites/1051/media_contents/90767

[9] GÜRSOY, E., "Unprincipled Approach" in the Contemporary Mosque Architecture . SDU Faculty of Arts and Sciences - Journal of Social Sciences, (2013), 239-253.

[10] BEGEÇ, H., \& UZUN, Ç., Mosque Architecture, Current Approaches. Yapı, (2011), 68-73.

[11] Photograph by NESLIHAN ONAT GÜZEL, (2016)

[12] KOCAGÖZ, Ş., Bir Bireşim Süreci: Bedirye Mencik Camisi (A Synthesis Process: Bedirye Mencik Mosque). Arredamento (264), (2013, Ocak), 62-67.

[13] KARABIBER, Z., A new approach to an ancient subject: Cahrisma Project. Germany: 7th International Congress on Sound and Vibration, (2000).

[14] ABDOU, A., Measurement of Acoustical Characteristics of Mosques in Saudi Arabia. The Journal of The Acoustical Society of America, 113(3), (2003, March), 505-1517. Doi:10.1121/1.1531982.

[15] ORFALI, W. A., Sound parameters in mosques. Proceedings of Meetings on Acoustics (153rd Meeting of Acoustical Society of America). Acoustical Society of America, (2007).

[16] HOSSAM ELDIEN, H., \& AL QAHTANI, H., The acoustical performance of mosques' main prayer hall geometry in the eastern province, Saudi arabia. Société Française d'Acoustique, Acoustics (2012), pp. 949-955. Nantes, France. Retrieved from https://hal.archives-ouvertes.fr/hal-00810652

[17] SÜ GÜL, Z., ÇALIŞKAN, M., \& TAVUKÇUOĞLU, A., Geçmişten Günümüze Süleymanyiye Camii Akustiği. Megaron, 9(3), (2014), 201-216. 
[18] Elkhateeb, A., AdAS, A., ATtia, M., \& BAlila , Y., The Acoustics of Masjids, why they differ from the Classical Speech Rooms. Proceedings of the 22nd International Congress on Sound and Vibration (ICSV22). 7/8, Florence, Italy: The International Institute of Acoustics \& Vibration, (2015), 5773-5780.

[19] KAYILI, M., Mimar Sinan'ın Camilerindeki Akustik Verilerin Değerlendirilmesi. In Mimarbaşı Koca Sinan: Yaşadığ 1 Çağ ve Eserleri, İstanbul: T.C. Başbakanlık Vakıflar Genel Müdürlüğü, 1988, pp. 545-555.

[20] SÜ, Z., \& YILMAZER, S., The Acoustical Characteristics of the Kocatepe Mosque in Ankara, Turkey, Architectural Science Review, 51(1), (2008), 21-30. Retrieved from http://dx.doi.org/10.3763/asre.2008.5104

[21] EL-KHATEEB, A., \& ISMAIL, M., Sounds From the Past The Acoustics of Sultan Hassan Mosque and Madrasa, Building Acoustics, 14(2), (2007), 109-132.

[22] KAVRAZ, M., The acoustic characteristics of the Carsi Mosque in Trabzon, Turkey. Indoor and Built Environment, 25(1), (2016), 128-136. doi:DOI: 10.1177/1420326X14541138

[23] KARABIBER, Z., \& ERDOĞAN, S., Comparison of the acoustical properties of an ancient and a recent mosque. Forum Acusticum. Seville, Spain: Spanish Acoustical Society (SEA), (2002).

[24] TOPAKTAŞ, L., Acoustical Properties of Classical Ottoman Mosques Simulation and Measurements, Ankara: The Graduate School of Applied and Natural Science of Middle East Technical University, (2003), 61.

[25] ISMAIL, M. R., A parametric investigation of the acoustical performance of contemporary mosques. Frontiers of Architectural Research, (2013-2).

[26] ZOHRA, B. H., The Numerical Simulation Support Tool for the Assesment of the Acoustic Quality of Worship Spaces. International Journal of Computer Science, Engineering and Information Technology, 6(1), (2016, February), 1-20. doi:10.5121/ijcseit.2016.6101

[27] CARVAlHO, A., \& AMADO, J., The acoustics of the Mekor Haim Synagogue, Portugal. Osaka: inter-noise. 2011.

[28] HAMMAD, R., Rasti measurements in mosques in Amman, Jordan. Applied Acoustics, 30(4), (1990), $335-345$.

[29] SÜ GÜL, Z., \& ÇALIŞKAN, M., Impact of design decisions on acoustical comfort parameters: Case study of Dogramacizade Ali Pasa Mosque. Applied Acoustics, 74, (2013), 234-244.

[30] GADE, A. C., Acoustics in Halls for Speech and Music (Part C/9). In T. D. Rossing (Ed.), Springer Handbook of Acoustics, LLC New York: Springer Science+Business Media, 2007, 301-350.

[31] ELKHATEeb, A., ADAS, A., ATTIA, M., \& BALILA, Y., The Acoustics of Masjids, Looking for Future Design Criteria. 23rd International Congress on Sound \& Vibration, ICSV23, 10-14, Athens, Greece. (2016 July).

[32] MEHTA, M., JOHNSON, J., \& ROCAFORT, J., Architectural Acoustics Principles and Design. New Jersey: PrenticeHall, Inc, 1999.

[33] KUTTRUFF, H., Room acoustics (5 ed.). New York: Spon Press, 2009.

[34] CARVALHO, Relations between rapid speech transmissionindex (RASTI) and other acoustical and architectural measures in churches. applied acoustics(58), (1999) 33-49.

[35] BS EN ISO 3382-2:2008, BS, Acoustics - Measurement of room acoustic parameters, Part 2: Reverberation time in ordinary rooms, 2008.

[36] SÜ GÜL, Z., Assessment of non-Exponential Sound Energy Decays within Multi-Domed Monuments by Numerical and Experimental Methods. The Graduate School of Natural and Applied Sciences . Ankara: METU (Middle East Technical University), (2015).

[37] SU GÜL, Z., \& ÇALIŞKAN, M., Acoustical design of Turkish Religious Affairs Mosque. Proceedings of Meetings on Acoustics (ICA 2013, Montreal), Montreal: Acoustical Society of America, Vol. 19, 015083, (2013), doi:10.1121/1.4800903 